\title{
Agrestal and Ruderal Weeds of some Crops in Abha, Saudi Arabia
}

\author{
Mahmoud F. M. Moustafa ${ }^{1,2^{*}}$, and Alwadi H. $\mathrm{M}^{2}$ \\ Botany Department, Faculty of science, south valley university, Qena 83523, Egypt ${ }^{1,2}$. \\ Department of Biological Sciences, College of Science, King Khalid University, Saudi Arabia ${ }^{2}$.
}

Rec. 7 Oct, 2010 Accpt. 12 Dec 2010

\begin{abstract}
In the present study agrestal and ruderal weeds flora associated within growing fields of; Cabbage, Fennel, Peppermint, Lettuce and Onion in Abha governorate, Saudi Arabia was reported. A total of 66 angiospermic species belonging to 28 families were found as ruderal weeds. Maximum numbers of species (17) were belonged to the family Poaceae followed by Asteraceae (9) and Solanaceae (5) Commicarpus grandiflorus and Rumex usambarensis were found to be the most frequently occurring and densely populated weeds with absolute frequency (AF) of $100 \%$ and absolute density (AD) of 5.69 and 8.14 respectively. The other frequently occurring and densely populated weeds were Argemone ochroleuca, Chenopodium murale, Convolvulus arvensis, Lycium shawii, Ochradenus baccatus, Solanum incanum and Sonchus oleraceus with (AF) ranging from 53-73\% and (AD) from 0.83-6.10. Less frequently occurring weeds with (AF) between $26-48 \%$ include fourteen species. The least frequently occurring species with (AF) $24 \%$ or below and (AD) from $0.02-0.77$ include forty three species. The results in the present study show dominance of the ruderal over the agrestal weeds which may be due to ploughing and cleaning of agricultural soil.
\end{abstract}

Key words: Agrestal, ruderal, weeds.

\section{Introduction}

Agriculture plays a crucial role in the economy of Saudi Arabia, so that weed surveys are useful for determining the occurrence and importance of weed species in crop production systems (Frick and Thomas, 1992). Documenting the kinds of weed species and its relative distribution facilitates the establishment of priorities for research and extension services (Mc Closky et al., 1998). Saudi Arabia is a large country with an arid climate in most parts of the regions. However, due to the topographic differences and variations in soil compositions, a significant number of species and plant associations can be seen in many places. The plant diversity of Saudi Arabia is relatively not simple, as one would expect for a desert' country. Rather, it is a complex flora having affinities with the floras of East Africa, North Africa, the Mediterranean countries and the IranoTuranian countries. The variation in climate and topography in the Asir region has led to the formation of diverse plant community (Abulfatih, 1984). Places of foggy cold climate dominated by Juniperus procera. Acacia trees are widely distributed to the east and west of Asir highland region. Communities of Ficus salicifolium and Ziziphus spina-christi var. spina-christi are common in the lowlands. Many other communities are found on the steep slopes to the west and south of the highlands. Communities of hydrophytes are found in lakes, ponds, and streams (Abulfatih, 1984). Meanwhile plant life in Saudi Arabia has raised the attention of numerous scholars; (Abulfatih 1991, 1992; Alfarhan 1999; Alfarhan 2000; Alfarhan et al., 1997; AlHemaid 1996; Al-Turki et al., 2000, 2001; Baierle et al., 1985; Boulos 1985, 1994; Collenette 1985; Ghafoor and Al-Turki 1999; Fayed et al., 1987; Fayed and Zayed, 1989). and many others. The aim of this study was to record weeds plants growing as agrestal and rudreal during growing season of some cultivated crops in Abha governorate, Saudi Arabia.

\footnotetext{
* Corresponding author:

Dr. Mahmoud F.M. Moustafa

$\bowtie$ hamdony@yahoo.com
} 


\section{Materials and methods}

\section{Site Description}

Abha governorate, Saudi Arabia is located in the south west of Saudi Arabia on the highland of Asir governorate. It is about of $90 \mathrm{~km}$ east of the Red Sea and about 220 $\mathrm{km}$ north of Yemen. It is situated in a hilly area, which drops gradually to the east. The landscape is featured by rolling lands, rocky hills, wadis, and permanently wet sites represented by the man made as Abha Lake. Soils in these habitats are sandy mixed with small sized rocks. It has climatic variation in temperature, rainfall and cloud formation coupled with the complex of topography. The area is under the influence of the prevailing south westerly winds during most of the year. These winds primarily originate in Africa and along the Arabian Sea and then pass over the Red Sea before reaching the Asir highlands. Mean annual rainfall recorded at Abha $332 \mathrm{~m}$, and the mean maximum temperature is about $22.4{ }^{\circ} \mathrm{C}$ and the minimum about $10{ }^{\circ} \mathrm{C}$ according the meteorological data from Abha governorate station.

\section{Field Surveys}

Field surveys of different crops growing areas in Abha governorate were conducted during the growing season of 2009-2010. Seven sites were selected to study weed distribution. Sampling was randomly done using $1 \times 1 \mathrm{~m}^{2}$ quadrat. According to Riaz et al., (2007), the data regarding prevalence, absolute, relative frequency, absolute and relative density of weeds were calculated by applying the following formulas; percentage of Prevalence $=$ (number of sites in which a specie occurs/Total number of sites) x 100, percentage of Absolute Frequency = (number of quadrates in which a specie occurs/Total number of quadrates) x 100 , percentage of Relative Frequency = (Absolute frequency value of a species/Total absolute frequency for all species) x 100 , percentage of Absolute density $=$ total number of individual of a species in all quadrates/Total number of quadrates and percentage of Relative density $=$ (Absolute density value of a species/Total absolute density for all species) x 100 .

\section{Results and discussion}

Weeds management in cultivated lands involve the use of many techniques and strategies, all with the goal of achieving weed control and maximal crop yields. Ideally, growers would like to achieve a level of zero weeds on their farms. In practice, this may not be achievable, but any reduction in weeds and in the amount of weed seed or perennial propagules reaching the soil will make subsequent weed control. For weeds to grow, they must have access of water, nutrients, and light (Bowman, 1997). Vise-versa, there are many reasons exert a control on weed growth inside the cultivated crops. Crops, which can grow vigorously, can often outcompete weeds. Crops that are well adapted to their planted areas are often better competitors for weeds since they will tend to occupy a site rapidly. In addition, a close-planted crop will close the canopy more rapidly, reducing the weeds' ability to compete. Some crops (including tomato, bean, and sweet corn) competed effectively with weeds, while others (including onion and garlic) never established a competitive canopy (Bowman, 1997).

In the present study, 66 weeds species belonging to (28) angiospermic families were found as a rudreal weeds in cultivated crops including; cabbage, fennel, peppermint, lettuce and onion. Maximum number of species (17) belongs to the family Poaceae followed by Asteraceae (9) and Solanaceae (5) were recorded.

As shown in (Table 1), Commicarpus grandiflorus, Lycium shawii, and Rumex usambarensis were found to be the most frequently occurring weed with relative frequency (RF) from 4.49-6.11\%, and they recorded in all seven studied fields showing $100 \%$ prevalence and absolute frequency (AF) of $73-100 \%$. Six species namely Argemone ochroleuca, Convolvulus arvensis, Datura stramonium var. stramonium, Ochradenus baccatus, Solanum incanum and Sonchus oleraceus showed $71 \%$ prevalence with absolute frequency (AF) from $42-63 \%$ and relative frequency (RF) from $2.62-3.87 \%$. Other six species namely Acacia etbaica, Aristida adscensionis, Chenopodium murale, Dichanthium annulatum, Reseda lutea and Schinus molle exhibited $57 \%$ prevalence 
with absolute frequency (AF) from $20-55 \%$ and relative frequency (RF) from 1.24$3.37 \%$. Fifty one species showed a low prevalence from $14-42 \%$ which are; Acacia pachyceras var. najdensis, Ageratum conyzoides, Aerva javanica, Aizoon canariense, Aloe vacillans, Amaranthus viridis, Arundo donax, Asparagus africanus, Asphodelus fistulosus, Avena fatua, Beta vulgaris, Brassica tournefortii, Calotropis procera, Chenopodium album, Crepis kotschyana, Cynodon dactylon, Diplachne fusca, Dodonaea viscosa var. viscosa, Echinops spinosus, Echium plantagineurn, Eragrostis cilianensis, Eragrostis minor, Eruca sativa, Eucalyptus globules,
Euphorbia prostrate, Ficus palmata, Forsskaolea tenacissima, Pulicaria undulata, Launaea arborescens, Cardaria chalepensis, Leptadenia pyrotechnica, Phragmanthera regularis, Malva parviflora, Panicum coloratum, Pennisetum setaceum, Pennisetum villosum, Phalaris minor, Phoenix dactylifera, Poa annua, Polypogon monspeliensis, Reichardia picroides, Reichardia tingitana, Rumex dentatus, Setaria pumila, Setaria verticilliformis, Sisymbrium irio, Solanum nigrum, Tetrapogon villosum, Withania somnifera, Xanthium strumarium and Ziziphus spinachristi var. spina-christi.

\begin{tabular}{|c|c|c|c|c|c|c|}
\hline Species & Family & $\begin{array}{c}\mathbf{P} \\
(\%)\end{array}$ & $\begin{array}{l}\text { AF } \\
(\%)\end{array}$ & $\begin{array}{l}\text { RF } \\
(\%)\end{array}$ & AD & $\begin{array}{l}\text { RD } \\
(\%)\end{array}$ \\
\hline Aizoon canariense L. & Aizoaceae & 14 & 10 & 0.62 & 0.10 & 0.16 \\
\hline Aerva javanica (Burm. f.) Juss. ex Schult. & Amaranthaceae & 42 & 14 & 0.87 & 0.26 & 0.42 \\
\hline Amaranthus viridis L. & “ & 42 & 30 & 1.87 & 2.65 & 4.25 \\
\hline Calotropis procera (Aiton) W.T.Aiton & Apocynaceae & 42 & 30 & 1.87 & 0.61 & 0.98 \\
\hline Schinus molle L. & Anacardiaceae & 57 & 20 & 1.24 & 0.40 & 0.65 \\
\hline Leptadenia pyrotechnica (Forssk.) Decne. & Asclepiadaceae & 14 & 10 & 0.62 & 0.14 & 0.22 \\
\hline Asparagus africanus Lam. & Asparagaceae & 14 & 10 & 0.62 & 0.10 & 0.16 \\
\hline Ageratum conyzoides L. & Asteraceae & 42 & 36 & 2.24 & 1.12 & 1.80 \\
\hline Crepis kotschyana Boiss. & “ & 14 & 6.0 & 0.37 & 0.34 & 0.55 \\
\hline Echinops spinosus L. & “ & 42 & 30 & 1.87 & 0.40 & 0.65 \\
\hline Pulicaria undulata (L.) C.A. Meyer. & “ & 14 & 4.0 & 0.24 & 0.10 & 0.16 \\
\hline Launaea arborescens (Batt.) Murb & “ & 42 & 24 & 1.49 & 0.42 & 0.68 \\
\hline Reichardia picroides (L.) Roth & “ & 28. & 18 & 1.12 & 0.26 & 0.42 \\
\hline Reichardia tingitana (L.) Roth & “ & 28 & 14 & 0.87 & 0.34 & 0.55 \\
\hline Sonchus oleraceus L. & “ & 71 & 61 & 3.74 & 3.06 & 4.90 \\
\hline Xanthium strumarium L. & “ & 14 & 2.0 & 0.12 & 0.02 & 0.03 \\
\hline Phoenix dactylifera L. & Arecaceae & 28 & 6.0 & 0.37 & 0.06 & 0.09 \\
\hline Echium plantagineurn L. & Boraginaceae & 42 & 36 & 2.24 & 0.40 & 0.65 \\
\hline Brassica tournefortii Gouan & Brassicaceae & 42 & 24 & 1.49 & 0.55 & 0.88 \\
\hline \multicolumn{7}{|l|}{ Eruca sativa Mill. subsp. lativalvis (Boiss.) } \\
\hline Greuter \& Burdet & “ & 28 & 6.0 & 0.37 & 0.38 & 0.62 \\
\hline Cardaria chalepensis (L.) Hand.-Maz. & “ & 14 & 2.0 & 0.12 & 0.10 & 0.16 \\
\hline Sisymbrium irio L. & “ & 28 & 28 & 1.74 & 6.12 & 9.81 \\
\hline Beta vulgaris L. & Chenopodiaceae & 28 & 10 & 0.62 & 0.14 & 0.22 \\
\hline Chenopodium album $\mathrm{L}$. & “ & 28 & 14 & 0.87 & 0.63 & 1.01 \\
\hline Chenopodium murale L. & “ & 57 & 55 & 3.37 & 2.14 & 3.43 \\
\hline Convolvulus arvensis L. & Convolvulaceae & 71 & 63 & 3.87 & 6.10 & 9.78 \\
\hline Euphorbia prostrata Aiton & Euphorbiaceae & 28 & 16 & 0.99 & 0.20 & 0.32 \\
\hline \multicolumn{7}{|l|}{ Acacia etbaica Schweinf. subsp. etbaica } \\
\hline Schweinf. & Fabaceae & 57 & 34 & 2.12 & 0.38 & 0.62 \\
\hline \multicolumn{7}{|l|}{ Acacia pachyceras Sw. var. najdensis } \\
\hline (Chaudhary) Boulos & “ & 28 & 20 & 1.24 & 0.22 & 0.36 \\
\hline Phragmanthera regularis (Steud. ex & Loranthaceae & 28 & 12 & 0.74 & 0.26 & 0.42 \\
\hline \multicolumn{7}{|l|}{ Sprague) M.G.Gilbert } \\
\hline Malva parviflora $\mathrm{L}$. & Malvaceae & 28 & 6.0 & 0.37 & 0.18 & 0.29 \\
\hline Ficus palmata Forssk. & Moraceae & 42 & 14 & 0.87 & 0.18 & 0.29 \\
\hline Eucalyptus globulus Labill & Myrtaceae & 28 & 12 & 0.74 & 0.14 & 0.22 \\
\hline Argemone ochroleuca Sweet & Papaveraceae & 71 & 55 & 3.37 & 2.67 & 4.28 \\
\hline Aristida adscensionis L. & Poaceae & 57 & 48 & 2.99 & 1.57 & 2.52 \\
\hline
\end{tabular}


Arundo donax L.

Avena fatua $\mathrm{L}$.

Cynodon dactylon (L.) Pers.

Dichanthium annulatum (Forssk.) Stapf

Diplachne fusca (L.) Kunth

Eragrostis cilianensis (All.) Vignolo ex Janch.

\section{Eragrostis minor Host}

Panicum coloratum L.

Pennisetum setaceum (Forsk.) Chiov.

Pennisetum villosum R.Br. ex Fresen

Phalaris minor Retz.

Poa annua L.

Polypogon monspeliensis (L.) Desf.

Setaria pumila (Poir.) Roem. \& Schult.

Setaria verticilliformis Dunart.

Tetrapogon villosum Desf.

Rumex dentatus L.

Rumex usambarensis (Dammer) Dammer

Aloe vacillans Forssk.

Asphodelus fistulosus L.

Commicarpus grandiflorus (A.Rich.) Standl

Ziziphus spina-christi var. spina-christi (L.)

Desf.

Ochradenus baccatus Delile

Reseda lutea L.

Dodonaea viscosa var. viscosa Jacq.

Datura stramonium var. stramonium L.

Solanum incanum L.

Solanum nigrum L.

Lycium shawii Roem. \& Schult

Withania somnifera (L.) Dunal.

Forsskaolea tenacissima L.

\begin{tabular}{|c|c|c|c|c|c|}
\hline “" & 42 & 12 & 0.74 & 0.42 & 0.68 \\
\hline ، & 28 & 22 & 1.37 & 0.30 & 0.49 \\
\hline ، & 42 & 30 & 1.87 & 0.38 & 0.62 \\
\hline “ & 57 & 40 & 2.49 & 1.02 & 1.63 \\
\hline “" & 14 & 10 & 0.62 & 0.14 & 0.22 \\
\hline “" & 28 & 8.0 & 0.49 & 0.14 & 0.22 \\
\hline “ & 14 & 2.0 & 0.12 & 0.04 & 0.06 \\
\hline “" & 14 & 2.0 & 0.12 & 0.06 & 0.09 \\
\hline “" & 42 & 26 & 1.62 & 0.46 & 0.75 \\
\hline “" & 42 & 18 & 1.12 & 0.34 & 0.55 \\
\hline “ & 14 & 6.0 & 0.37 & 0.34 & 0.55 \\
\hline “" & 42 & 18 & 1.12 & 0.67 & 1.08 \\
\hline “" & 42 & 14 & 0.87 & 0.28 & 0.45 \\
\hline “" & 42 & 10 & 0.62 & 0.26 & 0.42 \\
\hline “" & 42 & 18 & 1.12 & 0.22 & 0.36 \\
\hline “" & 42 & 14 & 0.87 & 0.26 & 0.42 \\
\hline Polygonaceae & 28 & 18 & 1.12 & 0.20 & 0.32 \\
\hline “ & 100 & 100 & 6.11 & 8.14 & 13.0 \\
\hline Liliaceae & 14 & 2.0 & 0.12 & 0.02 & 0.03 \\
\hline “ & 14 & 2.0 & 0.12 & 0.02 & 0.03 \\
\hline Nyctaginaceae & 100 & 100 & 6.11 & 5.69 & 9.13 \\
\hline Rhamnaceae & 28 & 14 & 0.87 & 0.14 & 0.22 \\
\hline Resedaceae & 71 & 61 & 3.74 & 1.83 & 2.94 \\
\hline “ & 57 & 46 & 2.87 & 0.85 & 1.37 \\
\hline Sapindaceae & 28 & 6.0 & 0.37 & 0.14 & 0.22 \\
\hline Solanaceae & 71 & 42 & 2.62 & 0.55 & 0.88 \\
\hline 6 & 71 & 53 & 3.24 & 0.83 & 1.34 \\
\hline “ & 28 & 6.0 & 0.37 & 0.18 & 0.29 \\
\hline “ & 100 & 73 & 4 & 4.06 & 6.51 \\
\hline “ & 28 & 14 & 0.87 & 0.18 & 0.29 \\
\hline Urticaceae & 42 & 16 & 0.99 & 0.63 & 1.01 \\
\hline
\end{tabular}

Table 1. Prevalence, Absolute frequency, Relative frequency; Absolute density, Relative density of weeds in growing fields of Cabbage, Fennel, Peppermint, Lettuce and Onion in Abha Governorate

The previous recorded weeds which recorded as a ruderal may be in the future will become the aggressive weeds in the cultivated crops due to their high reproductive potential, fast growth rate, allelopathic nature causing inhibiting of the root length, shoot length, and weight of cultivated crops (Dagar et al., 1976; Hussain et al., 1992; Navie et al., 1996; Singh et al., 2005; Batish et al., 2007). Also, it is reported that water extracts by various weeds caused inhibition in the length of plumule and radicle, as well as reduction in dry weight and total seedling weight in wheat, pea and lentil (Agarwal et al. 2002; Stavrianakou et al. 2004; and Dongre and Yadav, 2005). Also weeds reduced forage production by up to $90 \%$ (Nath, 1981). In India and Pakistan, Rumex dentatus L. is also of major concern in various crops of economic importance including wheat, since it is a highly competitive weed and can cause drastic yield reduction (Chhokar et al. 2007; Anjum and Bajwa 2007; Mehmood et al., 2007). Parasitic species like, Phragmanthera sp., which recorded in investigated area, it grows strongly on ageing trees particularly somewhere in the middle of old branches. Once established, it quickly steals the nutrients and sunlight by covering the encroached place such that the branch of the host tree is rendered weak and inactive. So that infestation weeds distribution within crops fields in studying area will give more information about quality and yield losses in crop production systems. Further studies may also be done to check allelopatic effects of various weed species recorded on agricultural crops.

$\mathrm{P}=$ Prevalence; $\mathrm{AF}=$ Absolute frequency; $\mathrm{RF}=$ Relative frequency; $\mathrm{AD}=$ Absolute density; $\mathrm{RD}=$ Relative density. 


\section{References}

Abulfatih, H.A. (1984). Wild plants from Abha and the surrounding areas. Saudia Publishing \& Distributing house, 125 pp.

Abulfatih, H.A. (1991). Quantitative assessment of wild trees in southwestern Saudi Arabia. Biological Sciences 1: 117-127.

Abulfatih, H.A. (1992). Vegetation zonation along an altitudinal gradient between sea level and $3000 \mathrm{~m}$ in southwestern Saudi Arabia. Jour. King Saud University, 4(1): 57-97.

Alfarhan, A.H. (1999). A phytogeographical analysis of the floristic elements in Saudi Arabia. Pakistan Journal of Biological Sciences 2 (3): 702-711.

Alfarhan, A.H. (2000). An account of the genus Croton L. in Saudi Arabia with a new record of C. bonplandianus Baill. Saudi Journal of Biological Sciences. 7 (1): 39-45.

Alfarhan, A.H., Thomas, J. and Alallah, M.I.H. (1997). Noteworthy records to the flora of Saudi Arabia. Kuwait Journal Science \& Engineering. 24 (1): 123130.

Al-Hemaid, F.M. (1996). Vegetation and distribution of the sand seas in Saudi Arabia, Geobios, 23: 2-15.

Al-Turki, T.A., Omer, S. and Ghafoor, A. (2000). A synopsis of the genus Atriplex L. (Chenopodiaceae) in Saudi Arabia. Feddes Repert. 111 (5-6): 255287.

Al-Turki, T.A., Omar, S. and Ghafoor, A. (2001). Two new species of Heliotropium L. (Boraginaceae) from Saudi Arabia. Botanical Journal of Linnean Society 137: 215-220.

Anjum, T., and Bajwa, R. (2007). Field appraisal of herbicide potential of sunflower leaf extract against Rumex dentatus. Field Crop Res., 100(2-3):139-142.

Agarwal, A.R., Gahlot, A., Verma, R. and Rao. P.B. (2002). Effect of weed extracts on seedling growth of some varieties of wheat. J Environ Biol 23: 19-23.

Baierle, H.V., EI-Sheikh, A.M. and Frey, W. (1985). Vegetation and flora in mittlern Saudi Arabia (at Taif - ar - Riyadh) In:Vegetation of Southwest Asia ed. By Kurschner, Tubinger Atlas Vord Orient, Beith, R.A. (Naturwiss) Wiesbaden.

Batish, D.R., Lavanya, K., Singh, H.P. and Kohli, R.K. (2007). Root mediated allelopathic interference of Nettleleaved Goosefoot (Chenopodium murale) on wheat (Triticum aestivum). J Agron Crop Sci 193: 37-44.

Boulos, L. (1985). A contribution to the flora of Asir mountains, Saudi Arabia. ArabGulf J Scient. Res. 3(1):67-94.

Boulos, L. (1994). Notes on Acacia Mill. Studies in the Leguminosae of Arabia:1 Kew Bull. 50(2): 327-337.

Bowman, G.D. (1997). Steel in the fields: farmer's guide to wee management tools Sustainable Agriculture Network.

Ghafoor, A. and Al-Turki, T.A. (1999). A new Anthemis (Asteraceae) from Saudi Arabia. Edinburgh Journal Botany 56 (1): 55-59.

Chhokar, R.S., R.K. Sharma, G.R. Jat, A.K. Pundir and Gathala, M.K. (2007). Effect of tillage and herbicides on weeds and productivity of wheat under rice-wheatgrowing system. Crop Prot. 26 (11):1689-1696.

Collenette, S. (1985). An illustrated guide to the flowers of Saudi Arabia. London.

Dagar, J.C., A.N. Rao and L.P. Mall. (1976): Regeneration of Parthenium hysterophorus. Geobios, 3: 202-203.

Dongre, P.N. and Yadav, B. (2005). Inhibitory allelopathic effect of weed leaf leachates on seed germination of pea (Pisum sativum L.). Crop Res Hisar 29: 458-461.

Fayed, A.A. Zayed, K. and Soliman, S. (1987): A contribution to the study of vegetation of Al Figra highland, Meddina (Saudi Arabia). Taeckholmia 10:33-55.

Fayed, A.A. and Zayed, K.M. (1989). Vegetation along Makkah-Taif road, Saudi Arabia. ArabGulf J Scient. Res. 7(3):79-117.

Frick, B. and Thomas, A.G. (1992). Weed surveys in different tillage systems in southwestern Ontario field crops. Can. J. Plant Sci. 72:1337-1347.

Hussain, F., Abidi, N., Ayaz, S. and Saljoqi, A.U.R. (1992). Allelopathic suppression of wheat and maize seedling growth by Imperata cylindrica (Linn). P Beauv. Sarhad J Agric 8: 433-437.

Mehmood, T.K., Khokhar, M. and Shakeel, M. (2007). Integrated weed management practices in garlic crop in Pakistan. Crop Protection. 26:1031-1035.

Mc Closky, W.B., Baker, P.B. and Sherman, W. (1998). Survey of cotton weeds and weed control practices in Arizona upland cotton fields. Publication AZ1006"cotton: College of Agric., Univ. Arizona. 
Nath, R. (1981). Note on the effect of Parthenium extract on seed germination and seedling growth in crops. Ind. J. Agric.Sci. 51:601-603.

Navie, S.C., McFayden, R.E., Panetta F.D. and Adkins, S.W. (1996). The biology of Australian weeds. 27. Parthenium hysterophorus L. Plant Protection Quart., 11: 76-88.

Singh, H.P., D.R. Batish, J.K. Pandher and Kohli, R.K. (2005). Phytotoxic effects of Parthenium hysterophorus residues on three Brassica species. Weed Biol. Mgmt. 5: 105-109.
Stavrianakou, S., Liakoura, V., Levizou, E., Karageorgou, P., Delis, C., Liakopoulos, G., Karabourniotis, G., Manetas, G. and Manetas, Y. (2004). Allelopathic effect of water-soluble leaf epicuticular material from Dittrichia viscose on seed germination of crops and weed. Allelopathy J 14: 35-41.

Riaz T., Khan, S.N., Javaid, A. and Farhan, A. (2007). Weed flora of Galdiolus fields in Lahore, Pakistan. Pak J. Weed Sci. Res. 13(1-2):113-120.

\section{الملخص العربى}

\section{التباتات البرية التي تنمو داخل وحول بعض الحقول في أبها_المملكة العربية السعودية محمود فوزي محمود \& عسين بن مانع الوادعي \\ قسم النبات، كلية العلوم، جامعة جنوب الو اديـ مصر ـ قسم علوم الحياة، كلية العلوم، جامعة الملكي خالد، المملكة العربية السعودية.}

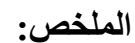

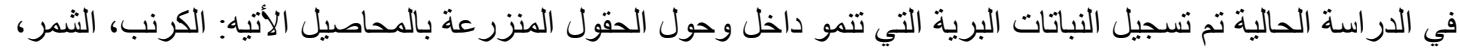

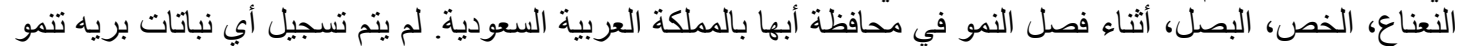

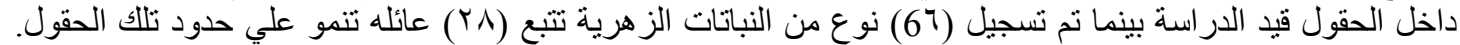

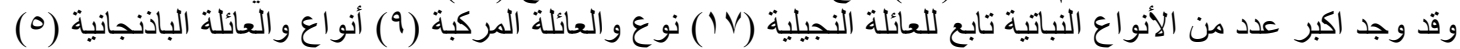

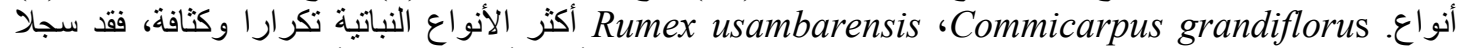

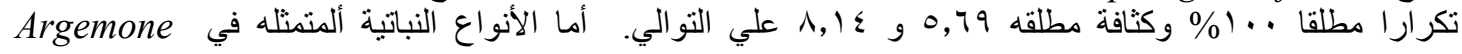
Ochradenus 'Lycium shawii 'Convolvulus arvensis 'Chenopodium murale 'ochroleuca

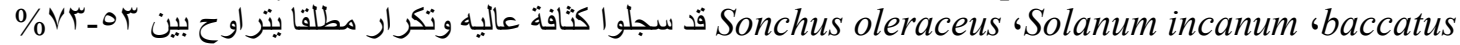

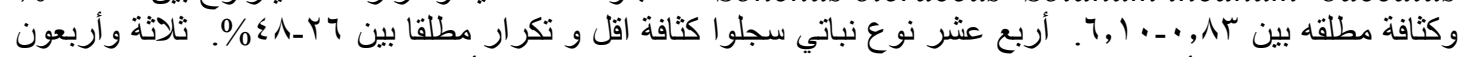

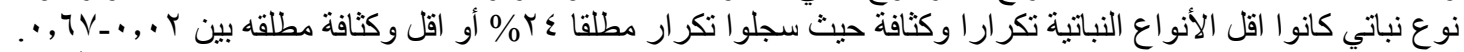

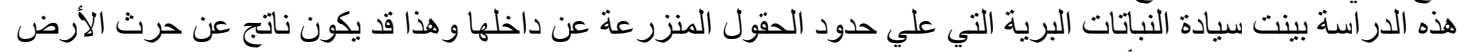
و إز الة النباتات البرية من الأر اضي الزيات البراية. 